\title{
曲げせん断を受ける長ほぞ差し込栓打ち接合部の力学的挙動に関する研究 EXPERIMENTAL STUDY ON FLEXURAL-SHEAR BEHAVIOR OF MORTISE-TENON JOINT WITH DOWEL
}

\author{
坂田弘安*, 山崎義弘**, 宇田川洋隆***, 大橋好光**** \\ Hiroyasu SAKATA, Yoshihiro YAMAZAKI, Hirotaka UDAGAWA \\ and Yoshimitsu OHASHI
}

\begin{abstract}
In this paper, moment resisting behavior of mortise-tenon joint with dowel is examined. At first, bending tests for mortise-tenon joint are conducted. A hundred and eight specimens are tested, and their parameters are dimension of tenon, post, beam and dowel and tree species of members. In addition, evaluation rule for moment resisting performance of mortise-tenon joint is proposed. It is based on the result of local compression test of wooden materials. Moment - rotation relationship of connection can be calculated by solving simplified equation of equilibrium.
\end{abstract}

Keywords : Traditional wooden structure, Mortise-tenon joint, Local compression characteristics, Bending moment-rotation relationship, Analysis model

伝統構法，長ほぞ差し込栓打ち，めり込み特性，曲げモーメント - 回転角関係，解析モデル

\section{1. 研究背景 $\cdot$ 目的}

伝統構法による木造建築物の耐震性能は、柱や横架材等の接合部 の構造性能の寄与が大きいことが分かっている。例えば、大橋らが 実施した伝統構法木造住宅の実大実験により、土壁のない軸組のみ の試験体でも $0.3 \sim 0.4$ 程度の最大ベースシア係数を有することが明 らかとなった 1)。つまり、軸組構法住宅のように壁の耐力のみを加 算する方法では、伝統構法住宅の真の耐震性能を評価することはで きないと言える。

また、骨組解析により伝統構法木造建築物の耐震性能評価を行う 場合、接合部を半剛接合としてモデル化する場合が多い。その場合、 接合部の復元力特性を的確に設定寸ることが解析の精度を高めるこ とに直結するため、非常に重要なことである。

本研究では、伝統構法における柱一横架材の仕口形式として全国 で7割強も用いられ、最も基本的な接合法と言える長ほぞ差し込栓 打ち接合部に着目した ${ }^{2)}$ 。長ほぞ差し込栓打ち接合部の曲げ性能に 関して、過去に様々な研究がなされているが、接合部の解析モデル の構築やそれに必要な実験データの収集は不十分と言える。例えば、 佐久間らが用いた力学モデルでは、木材の部分横圧縮実験結果から バネ剛性を算定し、接合部の回転中心をほぞの中央、つまり込栓の
位置と仮定して力の釣り合いを解いている ${ }^{3)}$ 。そのため、土台に対 する柱胴付面のめり込みが過大評価されるケースがある。西村らは 柱に圧縮力を同時に作用させた曲げ実験を行い、ほぞの歪分布を詳 細に計測することで、曲げ解析の力学モデルに要求される特性を考 察した ${ }^{4)}$ 。中尾らはほぞに一定の曲げモーメントを作用させた状態 で柱に引き抜き力を作用させる実験を行い、複合応力下での引き抜 き耐力の検討を行った ${ }^{5)}$ 。これらの研究より、接合部の解析モデル の構築に当たって、1) 木材の非線形めり込み性状を簡便かつ精度良 く再現でき、2) 込栓のせん断抵抗を考慮し、3）ほぞの破壊条件を 評価できる力学モデルが必要であることが示唆されている。

本研究では、まず長ほぞ差し込栓打ち接合部の曲げ実験を行い、 曲げ抵抗する際の接合部・込栓の力学的挙動を把握する。そして、 弾塑性領域に渡る曲げモーメント $M$ 一回転角 $\theta$ 関係を解析するた めの力学モデルを構築することが本論の目的である。提案する手法 は、等変位全面横圧縮実験のような簡便な実験から得られる木材の 構成則のみを用いて、接合部の $M-\theta$ 関係の包絡線を解析するも のである。また、木材の非線形めり込夕性状を最小単位とした力学 モデルを採用しているため、長ほぞ差し込栓打ち接合部以外の他の 接合部などの解析にも応用可能であると考えている ${ }^{9}$ 。

\footnotetext{
* 東京工業大学建築物理研究センター 准教授. 工博

** 東京工業大学大学院 修士 (工学) 日本学術振興会 特別研究員 $\cdot$ DC

***ミサワホーム佲) 修士(工学) (元 東京工業大学大学院)

**** 東京都市大学工学部建築学科 教授 $\cdot$ 工博

Assoc. Prof., Structural Engineering Research Center, Tokyo Institute of Technology, Dr. Eng.

Tokyo Institute of Technology, M. Eng.

JSPS Research Fellow

MISAWA HOMES CO., LTD., M. Eng.

(Former Graduate Student, Tokyo Institute of Technology)

Prof., Department of Architecture, Faculty of Engineering, Tokyo City University, Dr. Eng.
} 


\section{2. 接合部曲げ実験}

\section{1 実験概要}

図 1 に試験体詳細、表 1 に試験体一覧を示す。変動要因はほぞの 寸法、柱および横架材の断面寸法・樹種、込栓（樹種：カシ）の寸 法、込栓の有無(以下込栓無しの試験体を ND 試験体と称寸)である。 込栓の位置は、図 1 に示寸位置で全て統一した。1 種につき 6 体の 試験体を用意して実験を行った。

各試験体の名称を、次のように定義した。

$$
\text { (例) } \frac{\text { No.1 }}{\text { (1) }}-\frac{\mathrm{CH}}{\text { (2) }}-\frac{i}{(3)} \quad(i=1 \sim 6)
$$

(1) 試験体の寸法を表し、表 1 の名称に準ずる

(2) 柱と横架材の樹種を表す。C はスギ(Ceder), H はヒノキ (Hinoki cypress)である

(3) 同仕様の試験体の内、 $i$ 体目 $(i=1 \sim 6)$ であることを表す 試験体に用いた材料の平均含水率および平均気乾比重は、それぞ れスギが $15.7 \%, 0.48$, ヒノキが $14.8 \%, 0.58$ であり、カシの平均気 乾比重は 0.88 であった。

図 2 に曲げ実験のセットアップを示す。横架材をアンカーボルト (M16) により鉄骨架台に固定し、試験体 No.1, No.2 および ND 試験 体は横架材の材心から $700 \mathrm{~mm}$, 試験体 No.3 〜 No.6 は 715mm の高 さで載荷を行った。

載荷は絶対変位計測用フレームより計測した柱の部材角 $\gamma$ で制 御を行い、正負交番繰り返し載荷とした。 $\gamma=1 / 480$ から $1 / 21 \mathrm{rad}$. ま では正負 3 サイクルずつ繰り返し、1/15 rad. 以降は正側のみ 1 回の 載荷とした(図 3 参照)。ここで、部材角 $\gamma$ は次式より求める。

$$
\gamma=\left(\frac{u_{1}+u_{2}}{2}-\frac{u_{3}+u_{4}}{2}\right) / L
$$

ここに、 $u_{1}, u_{2}=$ 加力点の水平変位、 $u_{3}, u_{4}=$ 横架材の水平変位、 $L=$ 加力点から横架材心までの距離である。また、アクチュエータ の引き側を正載荷と定義した。載荷速度は、 $0.2 \mathrm{~mm} / \mathrm{sec}$. で一定とし た。ただし、除荷時には適宜変更した。

図 4 に計測状況を示す。アクチュエータの荷重（柱のせん断力）, 加力点と横架材の水平変位の他、接合部局所の相対回転角、浮き上 がりを計測した。

\section{2 実験結果}

加力点に与えた水平力から、接合部における危険断面位置での曲 げモーメント $M$ と、柱と横架材の相対変位から接合部の回転角 $\theta$ を 求めた。図 5 にNo.5-CC の $M-\theta$ 関係の一例を示寸。曲げモーメ ントは $1 / 15 \mathrm{rad}$.まで上昇し、非常に勒性に富んでいた。その後、孔 より先の端あき部でのせん断破壊によりモーメントが大きく低下し

1/480 1/21rad.まで正負 3 回繰り返し 1/15rad.からは正載荷側 1 回

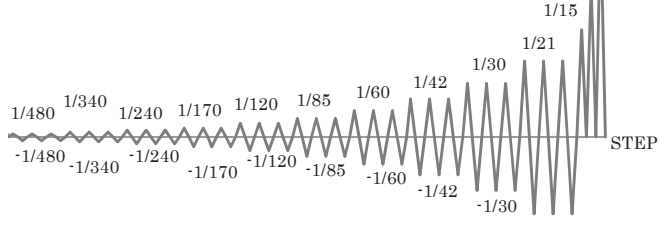

図 3 載荷サイクル
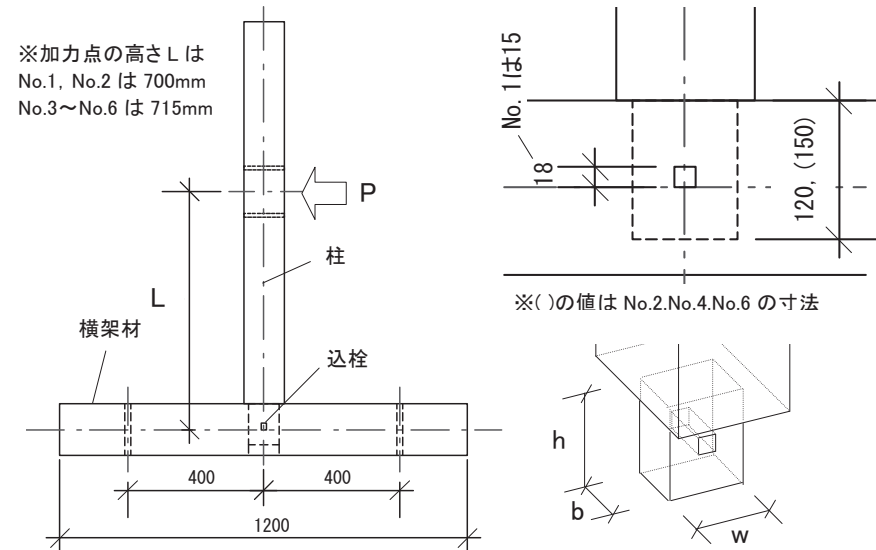

※( )の值は No.2.No.4.No.6 の寸法

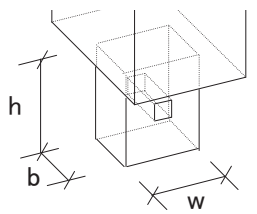

図 1 試験体詳細

\begin{tabular}{|c|c|c|c|c|c|c|c|c|}
\hline \multirow{2}{*}{ 試験体 } & \multirow[b]{2}{*}{ 柱 } & \multirow{2}{*}{ 横架材 } & \multirow{2}{*}{$\begin{array}{c}\text { ほぞ長 } \\
\text { h }\end{array}$} & \multirow{2}{*}{$\begin{array}{c}\text { ほぞ厚 } \\
\text { b }\end{array}$} & \multirow{2}{*}{$\begin{array}{c}\text { ほぞ幅 } \\
\text { w }\end{array}$} & \multirow{2}{*}{$\begin{array}{c}\text { 込栓 } \\
\mathrm{d}(\text { カシ) }\end{array}$} & \multicolumn{2}{|c|}{ 樹種 } \\
\hline & & & & & & & 柱 & 横架材 \\
\hline No.1-CC & 120 & 120 & \multirow{3}{*}{120} & \multirow{3}{*}{30} & \multirow{3}{*}{90} & \multirow{3}{*}{$15 \times 15$} & スギ & スギ \\
\hline No.1-CH & $x$ & $x$ & & & & & スギ & ヒノキ \\
\hline No.1-HH & 120 & 120 & & & & & ヒノキ & ヒノキ \\
\hline No.2-CC & 150 & 150 & \multirow{3}{*}{150} & \multirow{3}{*}{36} & \multirow{3}{*}{120} & \multirow{3}{*}{$18 \times 18$} & スギ & スギ \\
\hline No.2-CH & \multirow{2}{*}{$\begin{array}{c}\times \\
150\end{array}$} & $x$ & & & & & スギ & ヒノキ \\
\hline No.2-HH & & 150 & & & & & ヒノキ & ヒノキ \\
\hline No.3-CC & \multirow{14}{*}{$\begin{array}{c}120 \\
\times \\
120\end{array}$} & \multirow{14}{*}{$\begin{array}{c}120 \\
\times \\
150\end{array}$} & \multirow{3}{*}{120} & \multirow{6}{*}{30} & \multirow{14}{*}{90} & \multirow{3}{*}{$18 \times 18$} & スギ & スギ \\
\hline No.3-CH & & & & & & & スギ & 七ノキ \\
\hline No.3-HH & & & & & & & ヒノキ & ヒノキ \\
\hline No.4-CC & & & \multirow{3}{*}{150} & & & \multirow{3}{*}{$18 \times 18$} & スギ & スギ \\
\hline No.4-CH & & & & & & & スギ & ヒノキ \\
\hline No.4-HH & & & & & & & ヒノキ & ヒノキ \\
\hline No.5-CC & & & \multirow{3}{*}{120} & \multirow{6}{*}{36} & & \multirow{3}{*}{$18 \times 18$} & スギ & スギ \\
\hline No.5-CH & & & & & & & スギ & ヒノキ \\
\hline No.5-HH & & & & & & & ヒノキ & ヒノキ \\
\hline No.6-CC & & & \multirow{3}{*}{150} & & & \multirow{3}{*}{$18 \times 18$} & スギ & スギ \\
\hline No.6-CH & & & & & & & スギ & ヒノキ \\
\hline No.6-HH & & & & & & & ヒノキ & ヒノキ \\
\hline No.3-CC-ND & & & 120 & 30 & & \multirow{2}{*}{ 無 } & スギ & スギ \\
\hline No.6-CC-ND & & & 150 & 36 & & & スギ & スギ \\
\hline$\overline{\mathrm{D}: \text { No Dowel) }}$ & & & & & & & & \\
\hline
\end{tabular}

表 1 曲げ実験の試験体一覧

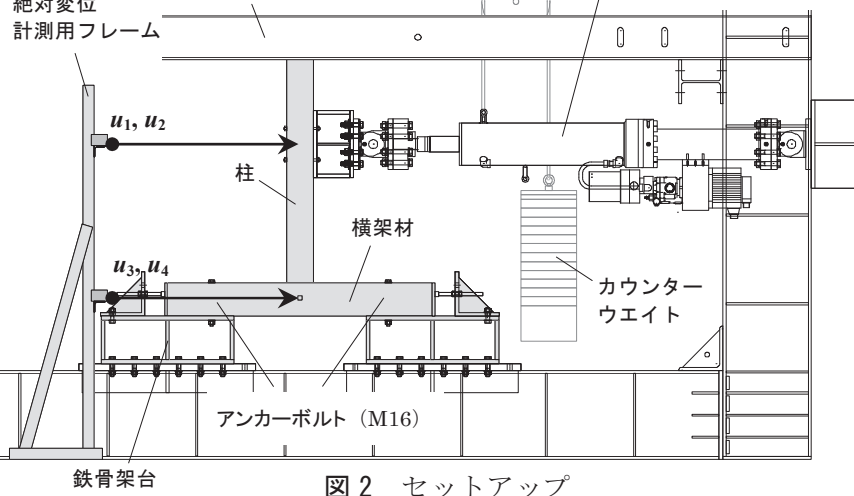

図 2 セットアップ

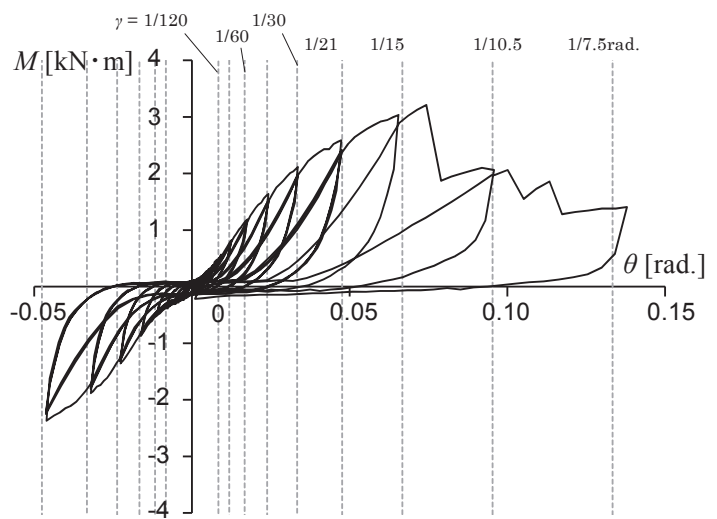

図 5 No.5-CC の $M-\theta$ 関係の一例 
表 2 各試験体の最大曲げモーメント

\begin{tabular}{|c|c|c|c|c|c|c|c|c|c|c|c|c|c|c|c|c|c|c|c|c|}
\hline \multirow{2}{*}{$\begin{array}{c}\mathrm{M}_{\max } \\
\mathrm{kN} \cdot \mathrm{m} \\
\end{array}$} & \multicolumn{3}{|c|}{ No.1 } & \multicolumn{3}{|c|}{ No. 2} & \multicolumn{3}{|c|}{ No. 3} & \multicolumn{3}{|c|}{ No.4 } & \multicolumn{3}{|c|}{ No. 5} & \multicolumn{3}{|c|}{ No.6 } & \multirow{2}{*}{$\frac{\text { No.3-ND }}{\text { CC }}$} & \multirow{2}{*}{$\frac{\text { No.6-ND }}{\text { CC }}$} \\
\hline & $\mathrm{CC}$ & $\mathrm{CH}$ & $\mathrm{HH}$ & $\mathrm{CC}$ & $\mathrm{CH}$ & $\mathrm{HH}$ & $\mathrm{CC}$ & $\mathrm{CH}$ & $\mathrm{HH}$ & $\mathrm{CC}$ & $\mathrm{CH}$ & $\mathrm{HH}$ & $\mathrm{CC}$ & $\mathrm{CH}$ & $\mathrm{HH}$ & $\mathrm{CC}$ & $\mathrm{CH}$ & $\mathrm{HH}$ & & \\
\hline 1 & 1.54 & 1.96 & 1.73 & 2.14 & 2.60 & 3.66 & 1.46 & 1.28 & 1.91 & 1.30 & 1.62 & 2.02 & 1.29 & 2.12 & 2.38 & 2.14 & 1.94 & 1.94 & 2.14 & 2.64 \\
\hline 2 & 1.63 & 1.61 & 1.54 & 2.21 & 4.01 & 3.48 & 1.64 & 0.84 & 1.93 & 1.65 & 1.53 & 1.79 & 1.36 & 2.12 & 1.92 & 1.86 & 1.82 & 1.80 & 1.25 & 2.34 \\
\hline 4 & 1.64 & 1.38 & 1.72 & 3.00 & 2.71 & 3.51 & 1.20 & 1.68 & 1.92 & 1.56 & 1.75 & 1.78 & 1.78 & 2.15 & 2.25 & 2.23 & 1.54 & 2.49 & 1.29 & 2.53 \\
\hline 5 & 1.47 & 1.50 & 2.04 & 3.12 & 3.19 & 3.19 & 1.58 & 1.68 & 2.15 & 1.58 & 1.56 & 2.34 & 1.60 & 1.89 & 2.26 & 2.56 & 2.00 & 2.23 & 1.82 & 2.09 \\
\hline 6 & 1.57 & 1.20 & 1.88 & 3.27 & 2.86 & 3.74 & 1.27 & 1.51 & 1.95 & 2.23 & 1.51 & 2.05 & 1.90 & 1.69 & 2.47 & 2.19 & 1.95 & 2.52 & 1.60 & 2.26 \\
\hline 平均値 & 1.54 & 1.61 & 1.74 & 2.71 & 3.08 & 3.61 & 1.43 & 1.50 & 1.91 & 1.67 & 1.64 & 1.98 & 1.65 & 1.96 & 2.23 & 2.18 & 1.84 & 2.19 & 1.54 & 2.26 \\
\hline 標淮偏差 & 0.10 & 0.32 & 0.20 & 0.49 & 0.57 & 0.30 & 0.17 & 0.41 & 0.18 & 0.31 & 0.13 & 0.21 & 0.28 & 0.19 & 0.20 & 0.23 & 0.17 & 0.29 & 0.39 & 0.33 \\
\hline
\end{tabular}

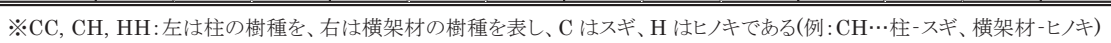

※No.2-CH-3 はデー夕損失の為、示していない。

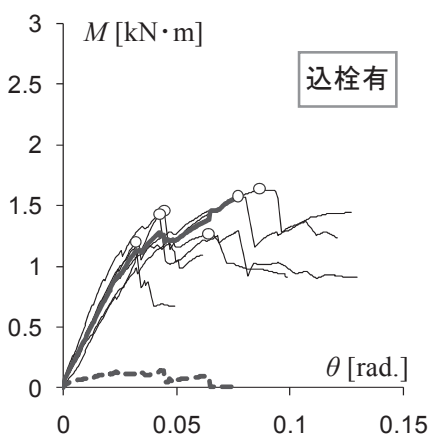

(a) No.3-CC

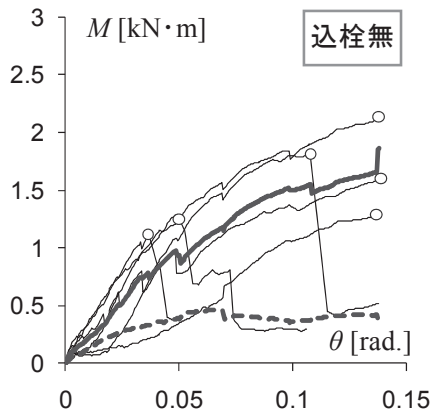

(c) No.3-ND-CC

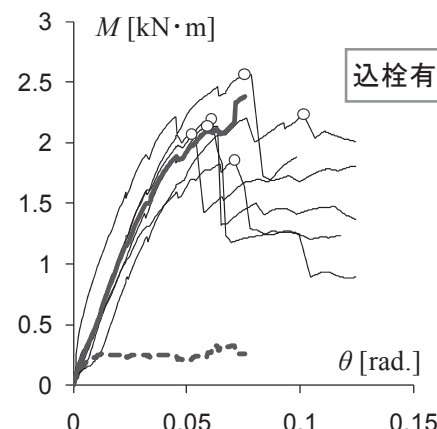

(b) No.6-CC

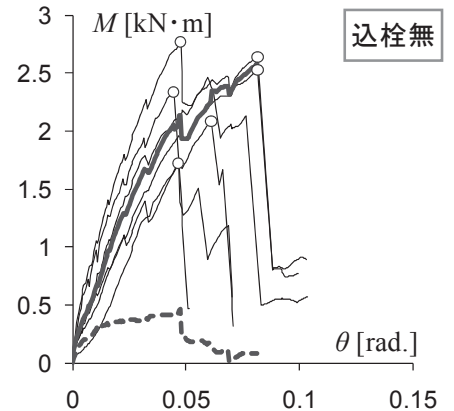

(d) No.6-ND-CC

—実験結果 —平均值 …標準偏差 ○ $M_{\max }$

図 6 No.3 №.6の $M-\theta$ 関係の包絡線

た。ほぞの破壊は、多くの試験体において、孔より先の端あき部で のせん断破壊、ほぞ側面の曲げ破壊の順で生じた（写真 1 )。

図 6(a),(b)はNo.3 と No.6の正載荷側の $M-\theta$ 関係の包絡線のみ示 しており、同一の $\theta$ に対する $M$ の平均值および標準偏差を併せて 示している。破壊後もしくは最大モーメント以降は当該試験体を除 外して残りの試験体で平均值と標準偏差を算出している。同種の試 験体においても、初期剛性や曲げモーメントの低下が生じる回転角 は 6 体で大きく異なったが、 $M_{\max }$ のばらつきは比較的小さかった。 初期剛性や曲げモーメントの低下が生じる回転角のばらつきは、木 材の節の位置や乾燥割れなどの材料的な影響の他に、加工の精度に よる影響が現れやすいものと考えられる。

表 2 に各試験体の最大曲げモーメントを示す。同一のほぞ長を有 するNo.3 と No.5 $(h=120 \mathrm{~mm}), \operatorname{No} 4$ と No.6 $(h=150 \mathrm{~mm})$ を比較する と、ほぞ幅が増加することで、樹種の組み合わせによらず、最大曲 げモーメントが約 10\%〜30\%ほど上昇する傾向がみられた(図 7)。

次に、樹種の違いによる影響を比較すると、いずれのグループも $\mathrm{HH}$ が最も最大曲げモーメントが高く、CC と $\mathrm{CH}$ ではグループによ って大小関係が異なっていた。No.4 と No.6では、CHよりも CCの 方が最大曲げモーメントの平均值が高く、これは、横架材がヒノキ
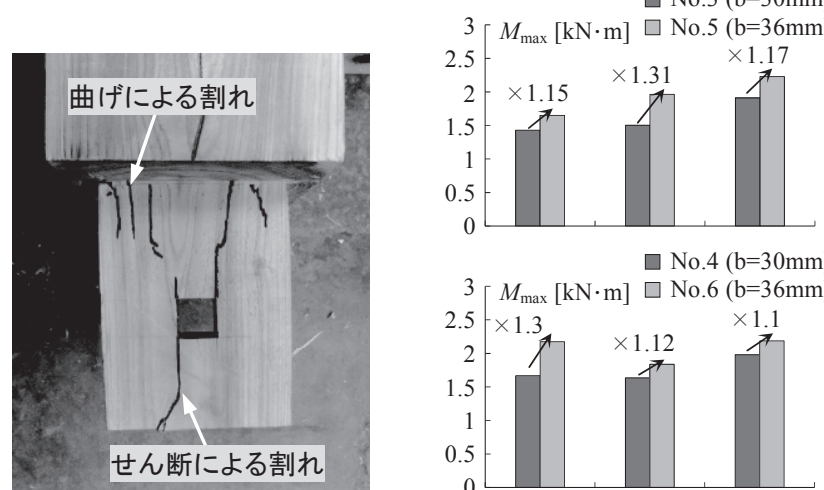

No.4 (b=30mm) $3\left[M_{\max }[\mathrm{kN} \cdot \mathrm{m}] \square \mathrm{No} .6(\mathrm{~b}=36 \mathrm{~mm})\right.$

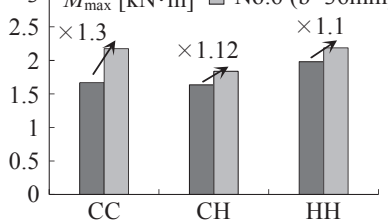

写真 1 曲げ実験後のほぞの損傷 図 7 最大曲げモーメントの比較

の場合に、柱に対する込栓の浮き上がり拘束が強くなるため、孔よ り先の端あき部でのせん断破壊が早期に生じたためである。端あき 部のせん断破壊が生じた後もほぞのめり込みにより曲げモーメント は上昇するため、横架材がスギの場合は変形性能が向上し、最大曲 げモーメントが高くなったと考えられる。また、後述する接合部曲 げ解析(4 章)においても同様の傾向が見られ、CHよりも CC の方が 端あき部のせん断破壊が生じる回転角が若干大きくなり、変形性能 が向上していた (図 17)。

続いて、込栓の有無の影響を述べる。No.3-CC と No.3-ND-CC, No.6-CC と No.6-ND-CC の比較を、それぞれ図 6(a)と(c), (b)と(d)に 示す。ND 試験体の方が、初期すべりをおこす試験体が多く、標準 偏差が大きくなる傾向がみられた。ほぞとほぞ孔にガタが生じてい る場合、込栓があることで柱の浮き上がりを抑え、柱の胴付と横架 材上面とのめり込みが早期に生じるため、曲げモーメントが初期状 態から上昇するが、込栓がないと柱の胴付面と横架材上面との接触 する位置でほぞが回転し、柱が浮き上がってしまう為に、ガタの影 響が顕著に現れたと思われる。

表 3 は No.3-CC, No.3-ND-CC, No.6-CC, No.6-ND-CC の最大曲げモ 一メントと、 $\gamma=1 / 30 \mathrm{rad}$.での柱の浮き上がり量の比較を示している。 これより、込栓があることで柱の浮き上がり量が $40 \%$ 程度減少して いることが分かる。なお、ND 試験体の最大曲げモーメントはほぞ の曲げ破壊によって決まっているものがほとんどで、込栓がある場 合とほぼ等しい最大曲げモーメントが得られた。

以上をまとめると、込栓は明らかに柱の浮き上がりを抑制する効 果があり、ほぞとほぞ孔のガタによって生じる小変形域での剛性低 下を減少させる傾向が見られた。また、込栓のせん断抵抗によって 生じる端あき部のせん断破壊は、接合部の破壊モード、つまり最大 曲げモーメントや接合部の変形性能を決定づける要因の一つでもあ り、よって、この部分の破壊現象を再現する実験を次章で示す。 
表 3 No.3 と No.6の最大曲げモーメント、柱の浮き上がり量、破壊状況

\begin{tabular}{|c|c|c|c|c|c|c|c|c|c|c|c|c|c|c|c|c|c|c|c|}
\hline \multicolumn{2}{|c|}{ 試験体名 } & $\begin{array}{l}\mathrm{M}_{\max } \\
\mathrm{kNm}\end{array}$ & $\begin{array}{l}\delta_{1 / 30} \\
\mathrm{~mm}\end{array}$ & 破壊性状 & \multicolumn{2}{|l|}{ 試験体名 } & $\begin{array}{l}\mathrm{M}_{\max } \\
\mathrm{kNm}\end{array}$ & $\begin{array}{l}\delta_{1 / 30} \\
\mathrm{~mm}\end{array}$ & 破壊性状 & \multicolumn{2}{|c|}{ 試験体名 } & $\begin{array}{l}\mathrm{M}_{\max } \\
\mathrm{kNm}\end{array}$ & $\begin{array}{l}\delta_{1 / 30} \\
\mathrm{~mm}\end{array}$ & 破壊性状 & \multicolumn{2}{|l|}{ 試験体名 } & $\begin{array}{l}\mathrm{M}_{\max } \\
\mathrm{kNm}\end{array}$ & $\begin{array}{l}\delta_{1 / 30} \\
\mathrm{~mm}\end{array}$ & 破壊性状 \\
\hline \multirow{6}{*}{ No.3-CC } & 1 & 1.46 & 0.80 & (1), (2) & \multirow{6}{*}{ No.3-ND-CC } & 1 & 2.19 & 0.70 & - & \multirow{6}{*}{ No.6-CC } & 1 & 2.14 & 1.27 & (1) & \multirow{6}{*}{ No.6-ND-CC } & 1 & 2.64 & 1.27 & (3) \\
\hline & 2 & 1.64 & 0.94 & (1), (2) & & 2 & 1.25 & 1.02 & (3) & & 2 & 1.86 & 0.64 & (1), (2) & & 2 & 2.34 & 1.09 & (3) \\
\hline & 3 & 1.43 & 1.07 & (1) & & 3 & 1.12 & 0.95 & (3) & & 3 & 2.07 & 0.64 & (1) & & 3 & 1.73 & 1.20 & (3) \\
\hline & 4 & 1.20 & 1.10 & (1), (2) & & 4 & 1.29 & 1.45 & - & & 4 & 2.23 & 0.96 & (1) & & 4 & 2.53 & 1.96 & (3) \\
\hline & 5 & 1.58 & 0.96 & (1) & & 5 & 1.82 & 2.14 & (3) & & 5 & 2.56 & 0.70 & (1) & & 5 & 2.09 & 1.18 & (3) \\
\hline & 6 & 1.27 & 0.65 & (1) (2) & & 6 & 1.60 & 2.14 & - & & 6 & 2.19 & 0.99 & (1) & & 6 & 2.26 & 1.55 & (3) \\
\hline \multicolumn{2}{|c|}{ 平均值 (Ave) } & 1.43 & 0.92 & & \multicolumn{2}{|c|}{ 平均值 (Ave) } & 1.54 & 1.40 & & \multicolumn{2}{|c|}{ 平均值 (Ave) } & 2.18 & 0.87 & & \multicolumn{2}{|c|}{ 平均値 (Ave) } & 2.26 & 1.38 & \\
\hline \multicolumn{2}{|c|}{ 最小值 (Min) } & 1.20 & 0.65 & & 最小值 (Mi & & 1.12 & 0.70 & & \multicolumn{2}{|c|}{ 最小值 (Min) } & 1.86 & 0.64 & & \multicolumn{2}{|c|}{ 最小值 (Min) } & 1.73 & 1.09 & \\
\hline \multicolumn{2}{|c|}{ 変動係数 $(\mathrm{CV})$} & 0.12 & 0.19 & & 変動係数 $(\mathrm{C}$ & & 0.26 & 0.45 & & \multicolumn{2}{|c|}{ 変動係数 $(\mathrm{CV})$} & 0.11 & 0.29 & & \multicolumn{2}{|c|}{ 変動係数 (CV) } & 0.14 & 0.24 & \\
\hline \multicolumn{2}{|c|}{ 標準偏差 } & 0.17 & 0.17 & & 標隻偏差 & & 0.41 & 0.62 & & \multicolumn{2}{|c|}{ 標準偏差 } & 0.23 & 0.25 & & \multicolumn{2}{|l|}{ 標準偏差 } & 0.33 & 0.33 & \\
\hline
\end{tabular}

$\delta_{1 / 30}$ : 接合部の回転角 $\theta=1 / 30 \mathrm{rad}$.時の横架材に対する柱の浮き上がり量

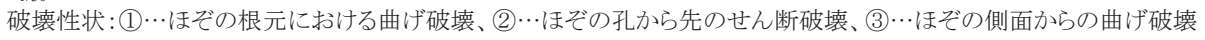
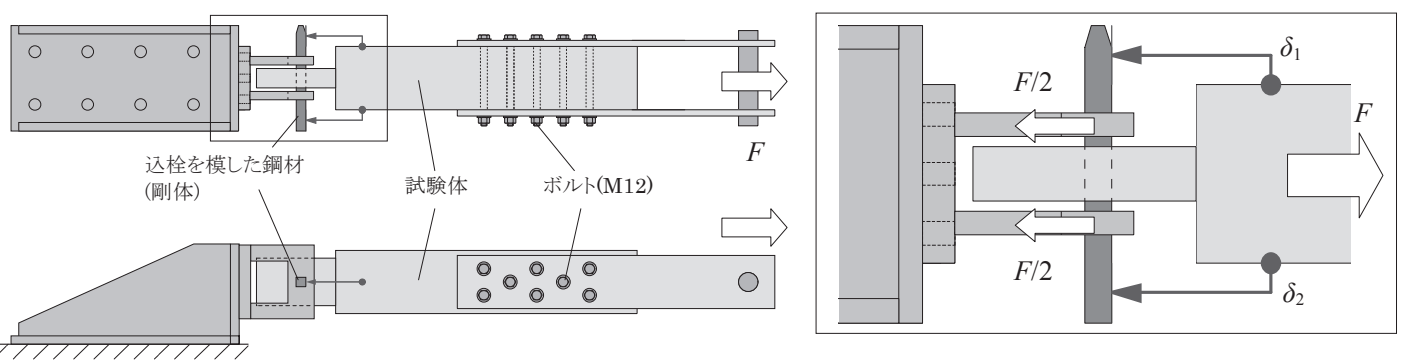

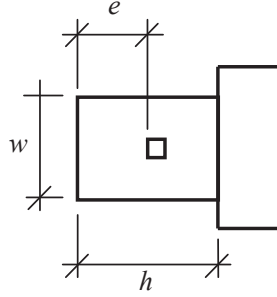

図 9 ほぞ寸法

図 8 載荷方法および計測方法(引張実験)

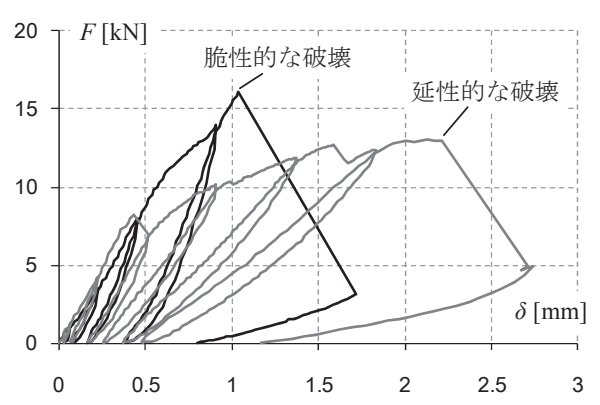

図 $10 \quad F-\delta$ 関係の例 (T-No.4-C)

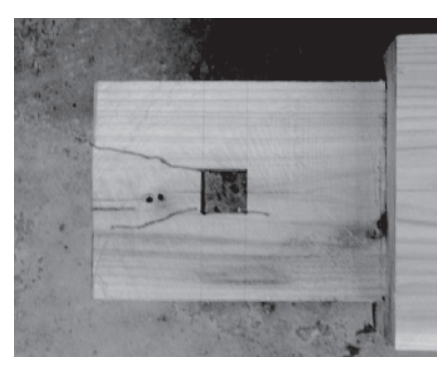

写真 2 引張実験後の ほぞの損傷状況

表 4 引張実験の試験体一覧

\begin{tabular}{|c|c|c|c|c|c|c|}
\hline 試験体名 & 柱断面 & $\begin{array}{l}\text { ほぞ長 } \\
h\end{array}$ & $\begin{array}{c}\text { ほぞ厚 } \\
b \\
\end{array}$ & $\begin{array}{c}\text { ほぞ幅 } \\
w \\
\end{array}$ & $\begin{array}{c}\text { 端あき } \\
e \\
\end{array}$ & 樹種 \\
\hline T-No.2-C & \multirow{2}{*}{$150 \times 150$} & \multirow{2}{*}{150} & \multirow{2}{*}{36} & \multirow{2}{*}{120} & \multirow{2}{*}{75} & スギ \\
\hline T-No.2-H & & & & & & ヒノキ \\
\hline T-No.3-C & \multirow{8}{*}{$120 \times 120$} & \multirow{2}{*}{120} & \multirow{4}{*}{30} & \multirow{8}{*}{90} & \multirow{2}{*}{45} & スギ \\
\hline T-No.3-H & & & & & & ヒノキ \\
\hline T-No.4-C & & \multirow{2}{*}{150} & & & \multirow{2}{*}{75} & スギ \\
\hline T-No.4-H & & & & & & 七ノキ \\
\hline T-No.5-C & & \multirow{2}{*}{120} & \multirow{4}{*}{36} & & \multirow{2}{*}{45} & スギ \\
\hline T-No.5-H & & & & & & 七ノキ \\
\hline T-No.6-C & & \multirow{2}{*}{150} & & & \multirow[b]{2}{*}{75} & スギ \\
\hline T-No.6-H & & & & & & 七ノキ \\
\hline
\end{tabular}

単位 $[\mathrm{mm}]$

表 5 各樹種のせん断強度

\section{3. 柱材の引張実験}

\section{1 実験概要}

前章の接合部曲げ実験で用いた試験体のほぞの孔より先の端あき 部におけるせん断強度、および破壞に至る挙動を把握するため、柱 材の引張実験を行った。図 8 亿載荷方法および計測方法を示す。込 栓を模した鋼材を反力にして柱の材軸方向に引張力を与え、ほぞの 孔より先に 2 面せん断を生じさせることで、極力接合部曲げ実験で 生じたせん断破壊に近い状態を再現した。

試験体の変動要因は、接合部曲げ実験に用いた寸法パラメータ 6 種類のうち、込栓の径 $d=18 \mathrm{~mm}$ としたものの 5 種類とし、樹種を スギとヒノキの 2 種、ばらつきを考慮し同種の試験体において 6 体 の実験を行った(図 9, 表 4)。試験体は 3 章で述べる接合部曲げ実験 と同じ木材より切出したものであり、平均含水率および平均気乾比 重は、それぞれスギが $13.1 \%, 0.41$ ，ヒノキが $11.1 \%, 0.51$ であった。 6 体の試験体のうち 1 体を単調載荷とし、その最大荷重 $P_{\text {max }}$ 時の 変形量 $\delta_{\max }$ を基準とし、残り 5 体は片側繰返し載荷とした。試験体 と込栓を模した鋼材の角棒との相対変位を変形量 $\delta$ とし、 $\delta=\left(\delta_{1}+\delta_{2}\right)$ 12 として求めた(図 8)。最終サイクル以降は、最大荷重の $50 \%$ 以下 に荷重が低下し、その後も荷重の増加が見られないと判断した時点

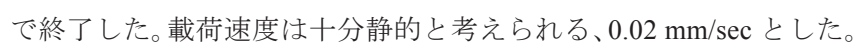

\begin{tabular}{|c|c|c|c|c|c|c|}
\hline \multirow{2}{*}{$\begin{array}{c}\text { 樹種 } \\
\text { 機械等級区分 }\end{array}$} & \multicolumn{3}{|c|}{ スギ } & \multicolumn{3}{|c|}{ "ヒノキ } \\
\hline & E70 & E90 & 全体 & E90 & E110 & 全体 \\
\hline 平均值 $\left[\mathrm{N} / \mathrm{mm}^{2}\right]$ & 2.13 & 2.27 & 2.18 & 2.79 & 3.05 & 2.85 \\
\hline 試験体数 & 20 & 10 & 30 & 23 & 7 & 30 \\
\hline 標準偏差 [N/mm²] & 0.66 & 0.43 & 0.60 & 0.88 & 0.64 & 0.84 \\
\hline 変動係数 & 0.31 & 0.19 & 0.30 & 0.32 & 0.21 & 0.29 \\
\hline 下限值を求めるための係数 $\mathrm{k}$ & 1.932 & 2.104 & 1.869 & 1.908 & 2.250 & 1.869 \\
\hline ばらつき係数 & 0.40 & 0.61 & 0.43 & 0.40 & 0.53 & 0.45 \\
\hline 基淮せん断強度 $F_{s, \text { exp }}\left[\mathrm{N} / \mathrm{mm}^{2}\right]$ & 1.47 & 1.88 & 1.61 & 2.19 & 2.58 & 2.30 \\
\hline 文献 7)による材料基準强度 $F_{s}\left[\mathrm{~N} / \mathrm{mm}^{2}\right]$ & \multicolumn{3}{|c|}{1.8} & \multicolumn{3}{|c|}{2.1} \\
\hline
\end{tabular}

\section{2 実験結果}

図 10 に試験体の $F-\delta$ 関係の一例を、表 5 に各樹種のせん断強 度を、写真 2 にほぞの破壊状況を示寸。試験体は、孔より先のせん 断面で徐々に割裂が入り、写真 2 に示すように 2 面でせん断破壊し た際に、1) 荷重が大きく低下寸る場合 (脆性的な破壊), 2) 荷重を保 持したままクラックが進行し、ある程度の塑性変形が生じた場合 (延性的な破壊) の 2 パターンが見られた。

表 5 の下 2 行に、実験から得たせん断強度の信頼水準 75\%の 5\% 下限值である基準せん断強度 $F_{s, \text { xxp }}$ と、文献 7）に記載される材料基 準強度 $F_{s}$ の比較を示す。スギは $F_{s, \text { exp }}$ が $F_{s}$ より低く、ヒノキは $F_{s, \text { exp }}$ が $F_{s}$ より高いが、いずれの樹種でも近い值であった。 


\section{4. 接合部曲げ解析}

\section{1 接合部の解析モデル}

長ほぞ差し込栓打ち接合部に外力として軸力 $N$ ・せん断力 $Q$. 曲げモーメント $M$ が作用したとき、接合部内に発生する内部応力 として図 11 に示す 4 種を定義した。すなわち、 $F_{c x 1}, F_{c x 2}=$ ほぞの側 面が横架材にめり込む抵抗力であり、添え字の「1」はほぞ先端側、「2」 はほぞ根本側の力を表す。また、 $F_{c y}=$ 柱胴付面が横架材上面にめり 込む際の抵抗力である。 $F_{f y 1}, F_{f y 2}=$ ほぞ側面と横架材の間に働く摩 擦力、 $F_{f x}$ 柱胴付面と横架材上面の間に働く摩擦力である。 $F_{d x}, F_{d y}=$ 込栓のせん断による抵抗力であり、添え字の「 $x\rfloor や 「 y 」$ は力の方向を 表す。これらの力は既往の研究や、 2 章の接合部曲げ実験での観察、 あるいは計測より得られたデータ分析結果を基に決定した。

ほぞは図 11 に黒丸で示す回転中心位置で剛体回転するとみなす ことで、上述の力は全て幾何学的な計算によって得られる。なお、 柱の浮き上がりに伴うほぞー横架材間の接触面積の変動は考慮しな い。原点をほぞ根本における中心にとり、回転中心までの距離をそ れぞれ $x_{n}, y_{n}$ とする。以上の前提条件の下、次節以降で各力の計算方 法を示し、力の釣り合いと変形の適合条件から接合部の $M-\theta$ 関 係を導く。

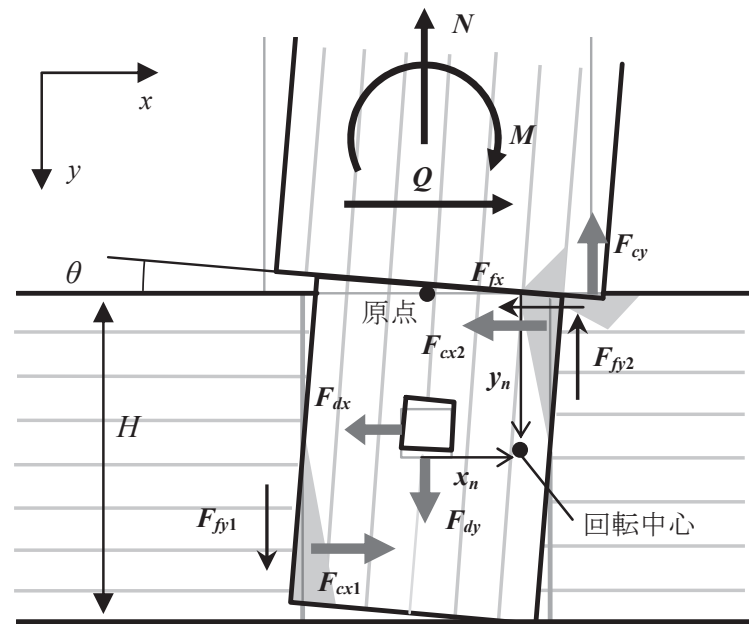

$F_{c x 1}, F_{c x 2}:$ ほぞのめり込みによる抵抗力

$F_{c y}$ : 横架材のめり込みによる抵抗力

$F_{f y 1}, F_{f y 2} F_{f x}$ : 摩擦力 (それぞれ、 $F_{c x 1}, F_{c x 2} F_{c y}$ に比例)

$F_{d x}, F_{d y}:$ 込栓のせん断による $x, y$ 方向抵抗力

$x_{n}, y_{n}:$ 原点から回転中心までの距離

図 11 接合部の応力状態

\section{2 めり込みによる抵抗力}

接合部の回転にともない木材の繊維直交方向に三角形状に生じる めり込みを、本論では「回転横圧縮」と呼ぶ。筆者らは図 12 に示す木 材同士の回転横圧縮実験を行うことで、摩擦力の影響を排除し、木 材の純粋な横圧縮性状を調べた ${ }^{8)}$ 。また、そこで得られる曲げモー メントー回転角関係が、等変位全面横圧縮実験の応力度一歪度関係 を用いた図 13 に示寸評価手順で推定可能であることも示した。その 手法をここで簡単にまとめる(詳細は付録 $\mathrm{A}$ を参照されたい)。

まず、等変位全面横圧縮実験で得られる応力度一歪度関係を、文 献 9)に示した手法でバイリニアに近似し、その第一勾配 $=E_{10}$, 第二 勾配 $=E_{20}$, 降伏応力度 $=\sigma_{y 0}$ とする。本論では接合部曲げ実験の試
験体から、比較的損傷が少なくかつ部材表面に節がない箇所を切り 出し、等変位全面横圧縮実験を行った。実験より得られた $E_{10}, E_{20}, \sigma_{y 0}$ をパラメータ毎に平均化し、表 6 にまとめて示す。

次に、回転横圧縮の構成則を求める。図 14 に示寸歪度分布からめ り込み抵抗力を求める場合、等変位全面横圧縮の構成則をそのまま 用いるのではなく、図 14(b)のように回転全面横圧縮の見かけの最大 縁応力度一最大縁歪度関係をバイリニアに近似した際に、第一勾配 $E_{1}=E_{10}$, 第二勾配 $E_{2}=E_{20}$, 降伏応力度 $\sigma_{y}=1.5 \sigma_{y 0}$ として 計算すれば、実験結果に良く 適合することが回転横圧縮実 験より分かった。また、木材 が部分的に横圧縮を受ける場 合には、加圧面からの余長の 寄与分を考慮する必要があり、 これは図 15 のように、加圧面
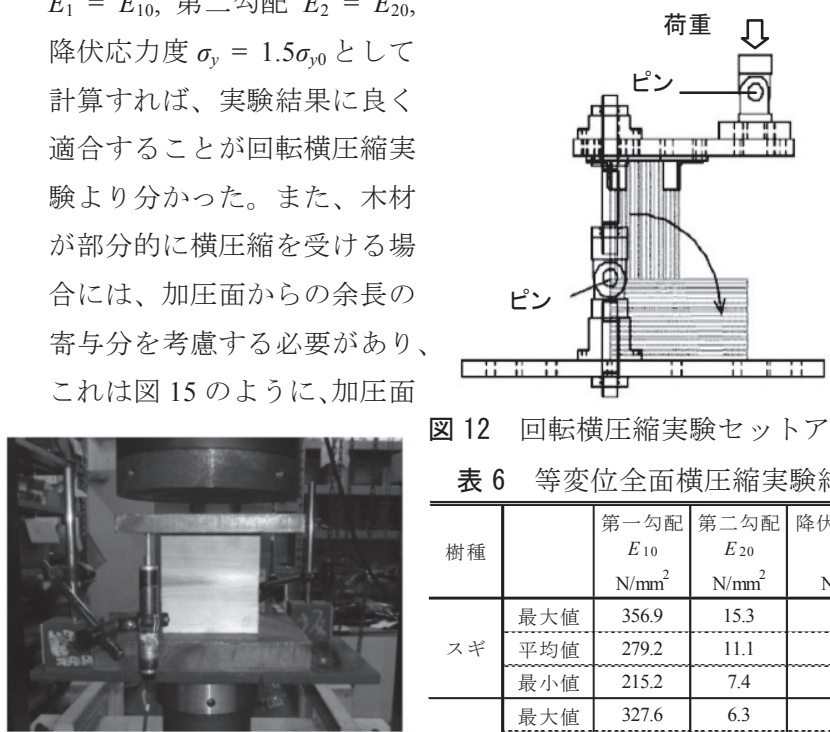

写真 3 等変位全面横圧縮実験

図 12 回転横圧縮実験セットアップ 8) 表 6 等変位全面横圧縮実験結果

\begin{tabular}{|c|c|c|c|c|}
\hline 樹種 & & $\begin{array}{c}\text { 第一勾配 } \\
E_{10} \\
\mathrm{~N} / \mathrm{mm}^{2}\end{array}$ & $\begin{array}{c}\text { 第二勾配 } \\
E_{20} \\
\mathrm{~N} / \mathrm{mm}^{2}\end{array}$ & $\begin{array}{c}\text { 降伏応力度 } \\
\sigma_{y 0} \\
\mathrm{~N} / \mathrm{mm}^{2}\end{array}$ \\
\hline \multirow{3}{*}{ スギ } & 最大值 & 356.9 & 15.3 & 6.5 \\
\hline & 平均值 & 279.2 & 11.1 & 5.8 \\
\hline & 最小值 & 215.2 & 7.4 & 4.6 \\
\hline \multirow{3}{*}{ ヒノキ } & 最大值 & 327.6 & 6.3 & 3.8 \\
\hline & 平均値 & 298.7 & 4.2 & 3.3 \\
\hline & 最小值 & 243.9 & 2.4 & 3.1 \\
\hline
\end{tabular}

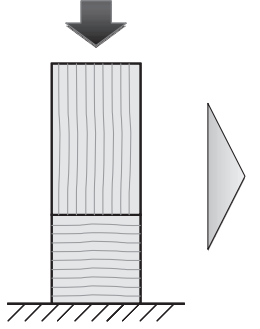

等変位全面横圧縮

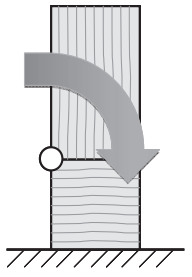

回転全面横圧縮

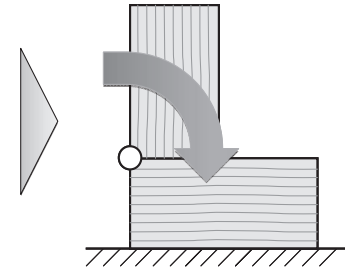

回転部分横圧縮
図 13 等変位横圧縮から回転横圧縮への評価方法
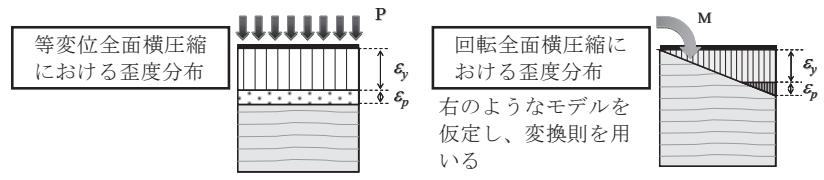

見かけの平均応力度 $\sigma$ いる

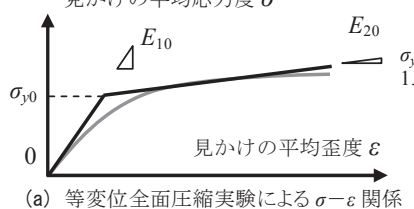

見かけの最大縁応力度 $\sigma$

図 14 回転横圧縮への変換

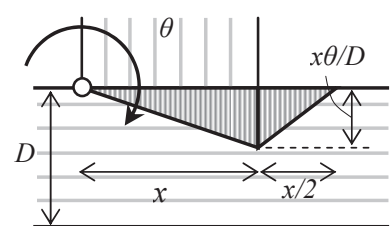

(a) 弾性時

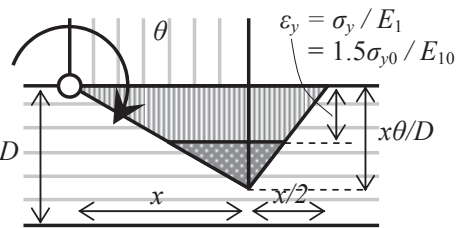

(b) 塑性時
図 15 余長の歪度分布 
の半分の長さだけ余長部に三角形状の歪が拡がるモデルとすること で、簡便に評価することができる ${ }^{8,9)}$ 。なお、ここで計算する力にお いて、木材の繊維方向のめり込みは考慮していない。

以上の定義に基づき、めり込みによる抵抗力 $F_{c x 1}, F_{c x 2}$ および $F_{c y}$ は弾性時において以下のように表せる。

$$
\begin{array}{ll}
F_{c x 1}=\frac{b\left(h-y_{n}\right)^{2} \theta E_{1 p}}{2 w} & \left(h-y_{n}\right) \theta / w \leq \varepsilon_{y p} \\
F_{c x 2}=\frac{3 b y_{n}^{2} \theta E_{1 p}}{4 w} & y_{n} \theta / w \leq \varepsilon_{y p} \\
F_{c y}=\frac{3 B\left(W / 2-x_{n}\right)^{2} \theta E_{1 b}}{4 H} & \left(W / 2-x_{n}\right) \theta / H \leq \varepsilon_{y b} \\
F_{c y}^{*}=\frac{b\left(w / 2-x_{n}\right)^{2} \theta E_{1 b}}{2 H} & \left(w / 2-x_{n}\right) \theta / H \leq \varepsilon_{y b} \quad(2 \mathrm{a}-\mathrm{d})
\end{array}
$$

ここで、 $B=$ 柱幅、 $H=$ 横架材せい、 $W=$ 柱せい、 $h=$ ほぞ長、 $w$ =ほぞ幅であり、 $E_{1}, E_{2}, \varepsilon_{y}$ の添え字「 $p$ 」,「 $b$ 」はそれぞれ「柱」,「横架材」 に用いた材料の特性值であることを表す。また、上記の $F_{c y}$ は横架 材にほぞ孔がない場合の力であるため、 $x_{n}<w / 2$ のときには、ほぞ 孔がない場合にほぞ孔位置に生ずるめり込みによる力 $F_{c y}^{*}$ を $F_{c y}$ か ら減じる必要がある。

なお、図 15(b)に示す余長部も含めた歪度分布形状は塑性域でも変 化せず、降伏歪度 $\varepsilon_{y}\left(=\varepsilon_{y} / E_{1}\right)$ を超える歪度に対しては、第二勾配 $E_{2}$ を用いることで、塑性化後の応力上昇を考慮する。

塑性後のめり込みによる抵抗力は以下のように表せる。

$$
\begin{aligned}
& F_{c x 1}=\frac{b\left(h-y_{n}\right)^{2} \theta E_{1 p}}{2 w}\left\{1-\left(1-\frac{E_{2 p}}{E_{1 p}}\right)\left(\frac{\left(h-y_{n}\right) \theta / w-\varepsilon_{y p}}{\left(h-y_{n}\right) \theta / w}\right)^{2}\right\} \\
& F_{c x 2}=\frac{3 b y_{n}^{2} \theta E_{1 p}}{4 w}\left\{1-\left(1-\frac{E_{2 p}}{E_{1 p}}\right)\left(\frac{y_{n} \theta / w-\varepsilon_{y p}}{y_{n} \theta / w}\right)^{2}\right\} \\
& F_{c y}=\frac{3 B\left(W / 2-x_{n}\right)^{2} \theta E_{1 b}}{4 H}\left\{1-\left(1-\frac{E_{2 p}}{E_{1 p}}\right)\left(\frac{\left(W / 2-x_{n}\right) \theta / H-\varepsilon_{y b}}{\left(W / 2-x_{n}\right) \theta / H}\right)^{2}\right\} \\
& F_{c y}^{*}=\frac{b\left(w / 2-x_{n}\right)^{2} \theta E_{1 b}}{2 H}\left\{1-\left(1-\frac{E_{2 p}}{E_{1 p}}\right)\left(\frac{\left(w / 2-x_{n}\right) \theta / H-\varepsilon_{y b}}{\left(w / 2-x_{n}\right) \theta / H}\right)^{2}\right\}
\end{aligned}
$$$$
\left(w / 2-x_{n}\right) \theta / H \leq \varepsilon_{y b}
$$

また、モーメントの算出において、余長部に生じた応力度の積分 值として求まる負担荷重は、三角形分布の最大縁応力度が生じる位 置に作用すると考える ${ }^{10)}$ (図 16)。

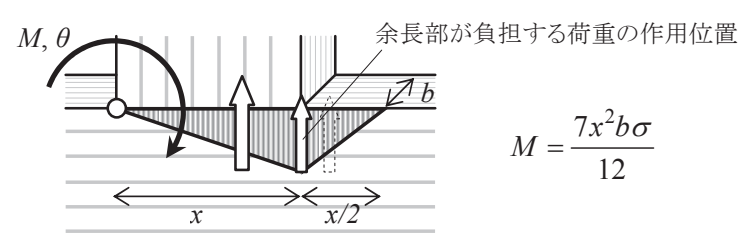

図 16 余長の寄与分のモーメントの評価

\section{3 摩擦力}

木材間に働く摩擦力をクーロン摩擦と仮定し、垂直抗力である $F_{c x 1}, F_{c x 2}, F_{c y}$ に摩擦係数 $\mu$ を乗じて求める。つまり、

$$
F_{f y 1}=\mu F_{c x 1}, \quad F_{f y 2}=\mu F_{c x 2} \quad, \quad F_{f x}=\mu F_{c y}
$$

2 章の接合部曲げ実験は静的載荷のため、木材間の摩擦として動 摩擦と静止摩擦を繰り返すような現象が観察された。そのため、摩 擦係数 $\mu$ は動摩擦係数之静止摩擦係数の 2 種類を用いた解析を行う (後述)。動摩擦係数は、柱・横架材がともにスギ $(\mathrm{CC})$ の場合は 0.22 , と もにヒノキ $(\mathrm{HH})$ の場合は 0.17 , 柱・横架材がスギ・ヒノキの $(\mathrm{CH})$ の 場合は 0.2 とし ${ }^{11)}$, 静止摩擦係数は樹種に関わらず 0.54 とした。

\section{4 込栓のせん断による抵抗力}

ほぞと横架材の相対ずれに対する込栓のせん断抵抗は、文献 12) を参照し、木ダボ接合（せん断抵抗型）の 2 面せん断として扱う。 込栓の中心位置における $x$ 方向・ $y$ 方向への滑り量をそれぞれ $\Delta x, \Delta y$ とし、各方向へ純粋なせん断力のみを与えた場合の初期剛性を $K_{d x}$, $K_{d y}$, 降伏耐力を $F_{d x, y}, F_{d y, y}$ とする。込栓の抵抗が弾性を保つとき、 $F_{d x}$, $F_{d y}$ は次式のように得られる。

$$
\begin{array}{ll}
F_{d x}=K_{d x} \Delta x \quad, & \Delta x=\left(\frac{h}{2}-y_{n}\right) \theta \\
F_{d y}=K_{d y} \Delta y \quad, & \Delta y=x_{n} \theta
\end{array}
$$

降伏耐力 $F_{d y, y}$ は、込栓の降伏耐力 (5つの降伏モード), ほぞの込 栓孔の端あき部でのせん断耐力、横架材の割裂耐力の最小值として おり ${ }^{12)}$, 端あき部でのせん断耐力は表 6 の $F_{s, \exp }$ 值を用いて $F_{s, \text { exp }} b h$ のように求めた(付録 B)。本論の試験体では、柱がスギの場合は端 あき部でのせん断耐力で、ヒノキの場合は込栓のせん断降伏で $F_{d y, y}$ が決まったが、両者はかなり近い值であった。3 章で示したように、 この部分の塑性変形能力は大きくばらつくため(図 10$), F_{d y}-\Delta y$ 関係 は完全弾塑性型でモデル化しておくが、多くの場合、降伏直後に破 壊が生じていると考えられる。また、後述する解析では $\Delta x$ が $\Delta y$ に 比べて非常に小さいため、2 方向に作用する力に対しても降伏条件 は互いに影響を与えないと仮定する。

初期剛性、込栓の降伏および横架材の割裂耐力などの算定式を付 録 B に示しておく。これらの算定に必要な面圧定数、面圧降伏応力 度などの材料特性值は、計測した密度による回帰式 ${ }^{12}$ や別途行った 3 点曲げ試験から得た曲げヤング係数を用いて求めた。

\section{5 カの釣り合い式}

外力 $N, Q, M$ に対する力の釣り合い式を解くことで、未知数であ る回転中心位置 $x_{n}, y_{n}$, せん断力 $Q$ を収斂計算により求める。ただし、 $M$ は接合部における危険断面位置での曲げモーメントのため $M=Q$ $(L-H / 2)$ の関係となり、さらに $N=0$ とする。まず、回転角 $\theta$ を 固定し、これに対する $Q, x_{n}, y_{n}$ を仮定することで、 $x$ 方向・ $y$ 方向の 力、および曲げモーメントの釣り合い式を次式のように立てる。

$$
\begin{aligned}
F_{c x 1}-F_{c x 2}-F_{d x}+Q & =0 \\
-F_{c y}+F_{f y 1}-F_{f y 2}+ & F_{d y}=0 \\
M_{c x 1}+M_{c x 2}+M_{c y}+ & F_{f x 1}\left(\frac{w}{2}-x_{n}\right)+F_{f x 2}\left(\frac{w}{2}+x_{n}\right) \\
& +F_{d x} y_{n}+F_{d y} x_{n}-Q(L-H / 2)=0
\end{aligned}
$$

ただし、 $M_{c x 1}, M_{c x 2}, M_{c y}$ は、それぞれ $F_{c x 1}, F_{c x 2}, F_{c y}$ による危険断面 位置での曲げモーメントである。ここで、まずは仮定した $Q$ を固定 


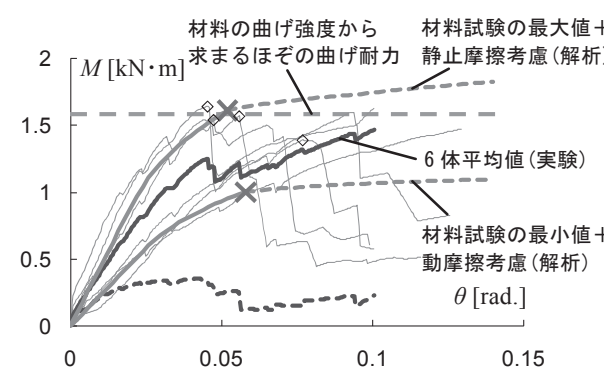

(a) No.1-CC

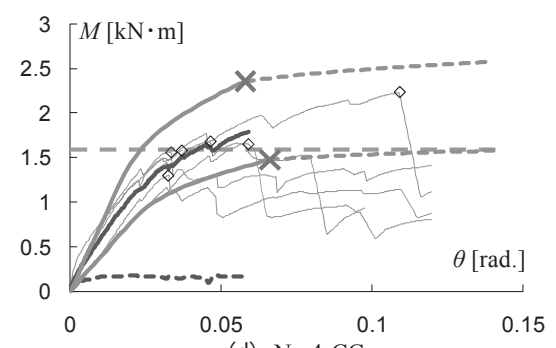

(d) No.4-CC
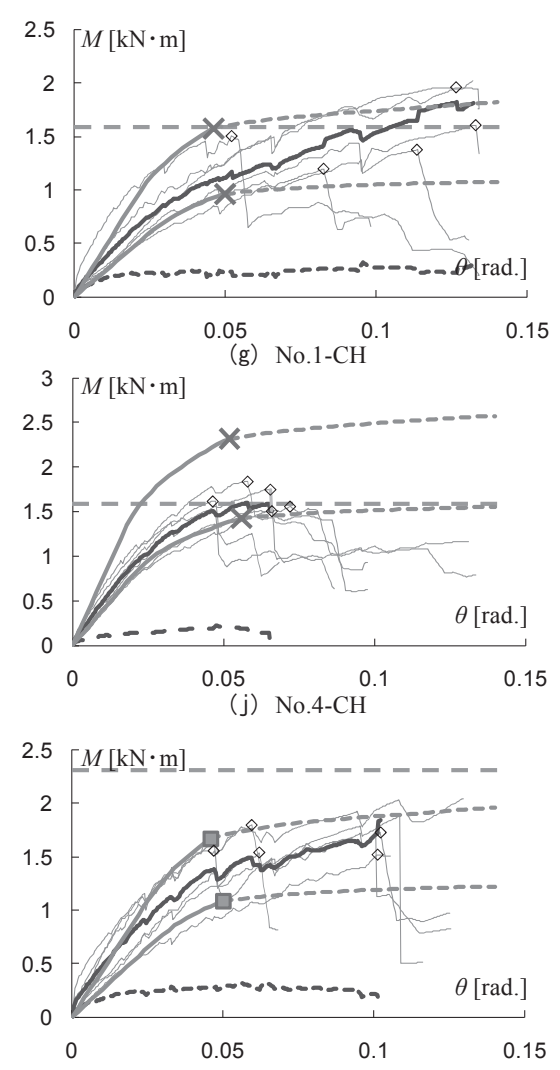

(m) No.1-HH

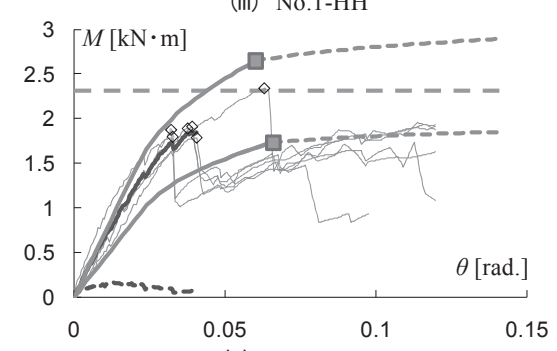

(p) No.4-HH

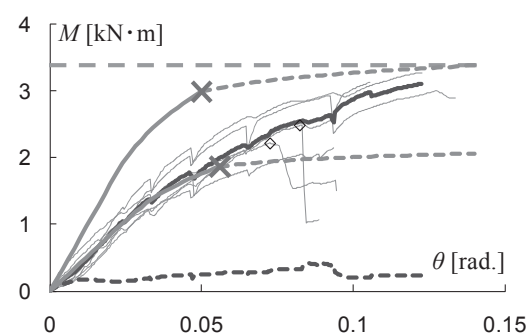

(b) No.2-CC

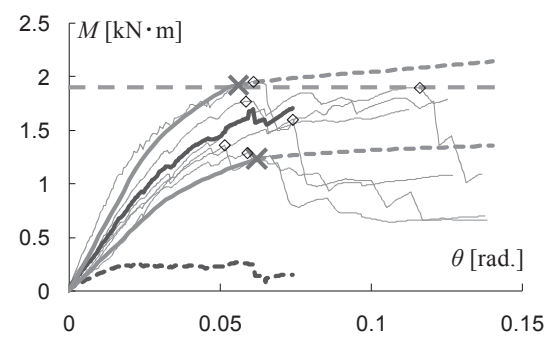

(e) No.5-CC
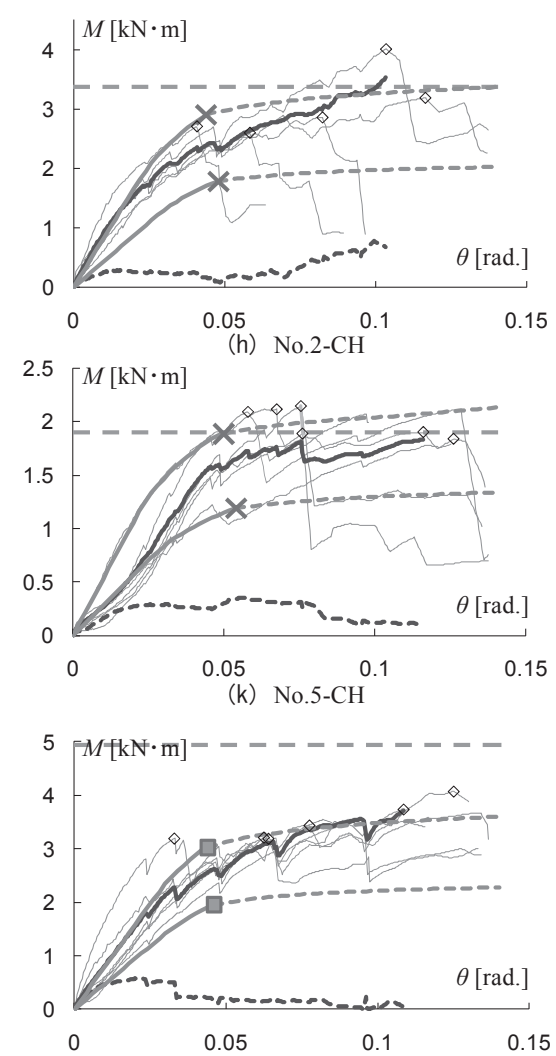

(n) No.2-HH

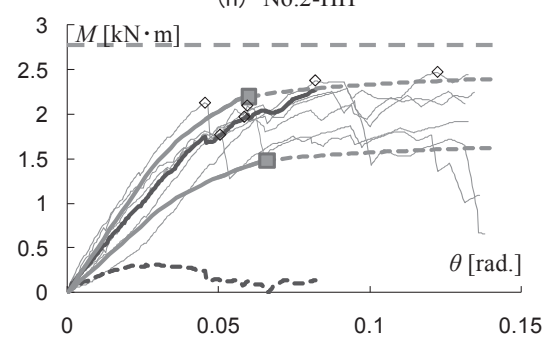

(q) No.5-HH

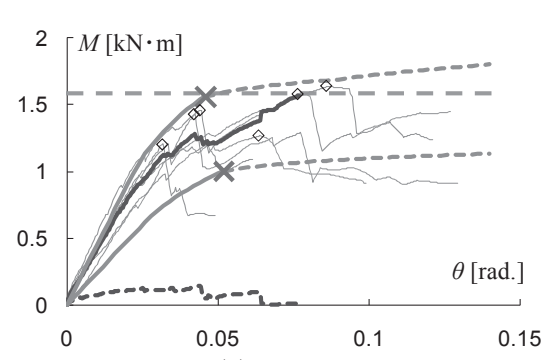

(c) No.3-CC

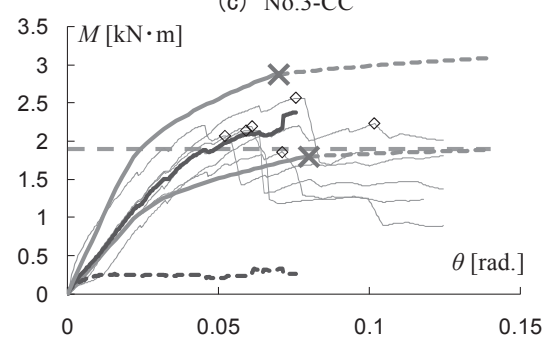

(f) No.6-CC
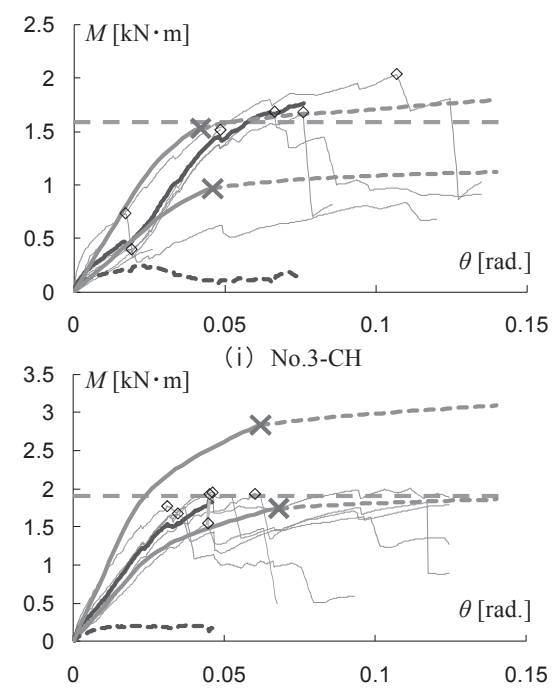

(I) No.6-CH

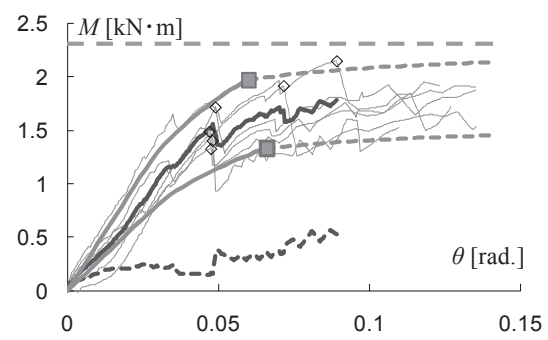

(o) No.3-HH

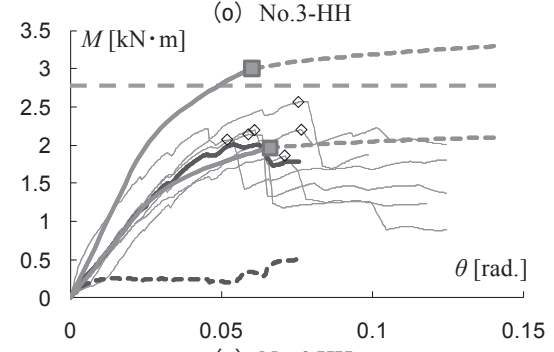

(r) No.6-HH

\begin{tabular}{|c|c|c|c|}
\hline 実 & 値(実験) & 一解 & $x t$ \\
\hline 破壊 (実験) & - - - - 標準偏差(実験) & n- - 解析結果 $\left(F_{d y}\right.$ 降伏後) & 口 込柏 \\
\hline
\end{tabular}

図 17 実験結果と解析結果の比較 
し、式(7a)を満たす未知数 $y_{n}$ を決定する。次に、 $Q$ および $y_{n}$ を固定 し、式(7b)を満たす未知数 $x_{n}$ を決定する。さらに、ここで得た $x_{n}, y_{n}$ を固定して式(7c)を満たす $Q$ を再計算し、得られた $\left(Q, x_{n}, y_{n}\right)$ が始め に仮定した $\left(Q, x_{n}, y_{n}\right)$ と大きく異なる場合には、新しい $\left(Q, x_{n}, y_{n}\right)$ を用 いて式(7a),(7b),(7c)を立て直し、収斂計算を行う。

以上がある回転角 $\theta$ での計算手順であり、 $\theta$ を逐次増加させてこ の計算を行えば、接合部の $M-\theta$ 関係が得られる。

なお、接合部内部の応力状態が点対称となる通し貫仕口に関して 棚橋らの研究があり、そこでは中立軸位置が自明のため $M-\theta$ 関 係を閉じた関数表現で定式化を行っている ${ }^{13)}$ 。また、めり込みに関 しても本論とは異なる構成則を用いている。本論は点対称でない仕 口の中立軸位置を詳細に求めている点が特徴と言えるが、将来的に は中立軸位置の計算の簡便化を図り、 $M-\theta$ 関係を閉じた関数で表 現することを考えている。

\section{5. 実験結果と解析結果の比較}

図17亿実験結果と解析結果の比較を示寸。実験值は各試験体の正 載荷側の $M-\theta$ 関係の包絡線と、それらの平均值、標準偏差を示し ている。また、解析結果は材料のばらつきを考慮するため、全面横 圧縮実験から得られた第一勾配 $E_{10}$ 、第二勾配 $E_{20}$ 、降伏応力度 $\sigma_{y 0}$ そ れぞれの最大值と最小值の 2 つを用いた結果を示した。そして、最 大值を用いた解析では静止摩擦係数を、最小值を用いた解析では動 摩擦係数を用いて摩擦力の計算 (4.3節) を行うことで、それぞれを 解析結果の上限值と下限值とした。さらに、込栓によるせん断抵抗 が降伏に至った後の挙動を破線で示し、3点曲げ実験から得た曲げ強 度にほぞ根本の断面係数を乗じて得る曲げ耐力も併せて示した。前 述の通り、破線が開始した後の変形性能は大きくばらつくため、安 全側に見れば破線が開始する点で破壊が生じると考えるべきである。

図17より、解析結果は全ての試験体において破壊点に至る手前ま での非線形化していく様子が追跡でき、本モデルの妥当性が確認で きた。また、全面横圧縮実験で得られる各特性值の最大值と最小值 を用い、さらに摩擦係数にも幅を持たせることで、 $M-\theta$ 関係のば らつきを概残推定できることが分かった(付録 $\mathrm{C}$ )。解析から求まる最 大曲げモーメントを、端あき部のせん断破壊か込み栓の降伏時のモ ーメント、あるいはほぞの曲げ耐力の最小值とすれば、実験の最大 曲げモーメントに近い值を予測できている。一方、破壊が生じると きの回転角は、ほぞの曲げ強度や横圧縮降伏応力度、孔より先の端 あき部におけるせん断降伏後の塑性変形能力などのばらつきに大き く左右され、精確な予測が困難であることが分かる。ちなみに、 No.1-CCの解析では、弾性時に $x_{n}=36 \sim 40 \mathrm{~mm}, y_{n}=54 \sim 55 \mathrm{~mm}$ であり、 ほぼ図11に示した通りの位置に中立軸が存在した(他の試験体も同 様)。塑性化後も $10 \mathrm{~mm}$ 以下の小さな変動しか生じなかった。中立軸 位置は込栓に作用する力の計算に直結するため(式(5),(6)), これを 合理的に定めることが破壞点を推定する上で重要となる。

本論では始めに生じた破壊後の挙動、つまり耐力低下やその後の 耐力の再上昇などの挙動は再現していないが、始めに生じる破壊点 は、いずれの試験体でも $1 / 20 \mathrm{rad}$.を超える大変形域であった。ゆえに、 本解析で得られる結果は、許容応力度計算はもちろん、保有水平耐 力計算をベースとした設計法に対しても、十分適用可能なものと言 える。今後は、除荷や再載荷後に生じるスリップ性状を考慮するこ
とで、接合部のエネルギー吸収の評価、ひいては限界耐力計算や骨 組の時刻歴解析に用いる履歴モデルへの展開が課題となるだろう。

\section{6. まとめ}

本論では、まず長ほぞ差し込栓打ち接合部の曲げ実験を行い、曲 げモーメントー回転角関係や破壞性状などを把握した。そして、こ れらを評価できる解析法を提案した。以下にまとめる。

・実験で得た曲げモーメントは1/20rad.程度まで上昇し、非常に勒性 に富んでいた。同種の6体の試験体で、初期剛性や曲げモーメント の低下が生じる回転角は加工精度の影響も受けることで大きく異 なったが、 $M_{\max }$ のばらつきは比較的小さかった。

・ほぞの破壊は、多くの試験体で (1) 孔より先の端あき部でのせん 断破壞(込栓がある試験体)，(2) ほぞ側面の曲げ破壊の順で生じた。 ・接合部に込栓を用いない試験体に曲げモーメントを与えた場合、 込栓を用いた試験体に比べて横架材に対する柱の浮き上がり量が 40\%程度大きくなる傾向がみられ、曲げに対しても込栓が柱の浮 き上がりを拘束していることが分かった。

・ 孔より先の端あき部でのせん断破壊を再現するため、柱の引張実 験を行い、せん断強度や変形性能を把握した。せん断強度は文献 7)の材料基準強度 $F_{s}$ でほぼ代用できることが分かった。

・提案する力学モデルの曲げ解析により、接合部に始めに生じる破 壊点までの包絡線が精度良く予測できた。

- 全面横圧縮実験で得られる見かけの平均応力度 $\sigma$ 一見かけの平均 歪度 $\varepsilon$ 関係をバイリニア化した際の第一勾配 $E_{10}$, 第二勾配 $E_{20}$, 降 伏応力度 $\sigma_{y 0}$ のそれぞれの最大值と最小值を用い、さらに摩擦係数 にも幅を持たせることで、 $M-\theta$ 関係のばらつきを概ね推定でき ることが分かった。

なお、本論では柱に軸力が作用しない場合を対象としたが、式(7b) 左辺に軸力 $N$ 加えることで、同様の解析が可能と考えられる。実 験との整合性検証を含め、今後の課題としたい。

\section{謝辞}

この実験は、「一般社団法人 木を活か寸建築推進協議会」が、国 土交通省の補助を受けて進めてきた「伝統的木造軸組構法住宅の耐 震性能検証実験事業」の一環として行われたものである。関係者各 位に謝意を表する。

\section{参考文献}

1）大橋好光，的野博訓，中川貴文，前川秀幸，河合直人，松留㥀一郎: 伝統的 構法による木造軸組住宅の実大水平加力実験 その 1 その 4, 日本建築 学会大会学術講演梗概集, C-1 分冊, pp.579-586, 2010.9

2) 財団法人 日本住宅・木材技術センター：伝統的木造軸組工法住宅の耐震 性能検証実験報告書，平成 20 年度国土交通省補助事業報告書, pp.249-279, 2008

3) 佐久間譲, 春山聡子, 後藤正美，西村督，稲山正弘，鈴木祥之:木材の特性 を考慮した木造軸組工法のほぞ差し接合部解析モデルの提案その 2 実 験と解析の比較, 日本建築学会北陸支部研究報告集(51), pp.125-128, 2008.7

4) 西村督, 後藤正美, 鈴木祥之: 木造軸組構法における長ほぞ込栓打ち接合 部の応力伝達に関する実験的研究，日本建築学会構造系論文集，第 658 号， pp.2197-2204, 2010.12

5) 中尾方人, 後藤正美, 鈴木祥之 : 曲げモーメントが作用する長ほぞ込栓打 ち仕口の引抜き耐力 作用する曲げモーメントが一定の場合, 日本建築学 会構造系論文集，第 663 号,pp.951-958, 2011.5 
6) 宮木志伸, 坂田弘安, 山崎義弘, 伊東洋路, 藤代東, 大口仁, 小谷竜城： ラグスクリューボルトと鋼板挿入式ドリフトピン接合を用いた木質接合 部の曲げせん断挙動に関する実験研究その 2 接合部の断面解析, 日本 建築学会大会学術講演梗概集, C-1 分冊, pp.343-344, 2011.8

7) 日本建築学会, 丸善: 木質構造設計規準 - 同解説一許容応力度 - 許容而力 設計法一, 第 4 版第 2 刷, p.395, 2009.3

8) 松原洋介, 杜重堅, 坂田弘安, 和田章, 伊東洋路, 片岡良二:米松集成材同 士のめり込み挙動に関する実験的研究, 日本建築学会大会学術講演梗概 集, C-1 分冊, pp.27-28, 2002.8

9) 坂口裕美, 坂田弘安, 中田捷夫, 中野棇久, 伊東洋路, 片岡良二: ドリフト ピン・ハンガー接合システムを用いた木質半剛接合部の力学的挙動に関 する実駼研究 その $2 \mathrm{M}-\theta$ 算定式, 日本建築学会大会学術講演梗概集, C-1 分冊, pp.127-128, 2006.7

10) 稲山正弘: 木材のめり込み理論とその応用, 東京大学学位論文, 1991

11) 森林総合研究所, 丸善 : 木材工業ハンドブック,pp.128-129, 2004

12）日本建築学会, 丸善: 木質構造接合部設計マニュアル,pp.102-104, 2009.11

13）棚橋秀光, 鈴木祥之：伝統木造仕口の回転めり込み弾塑性特性と十字型 通し貫仕口の定式化, 日本建築学会構造系論文集, 第 667 号, pp.1675-1684, 2011.9

\section{付録 A めり込み抵抗力の算出}

文献 8)で行った木材同士の回転横圧縮実験から得た結果を概説しながら、 4.2 節で示しためり込み抵抗力の算出方法の根拠を述べる。

1) 等変位全面横圧縮から回転全面横圧縮への変換則

回転全面横圧縮によるめり込み抵抗力やそれによるモーメントを計算する 際、図 14 右の上うな歪度分布を仮定し、そこから応力度を計算できれば扱い やすい。そこで、仮定した三角形の歪度分布に対して縁歪度と縁応力度の関 係で実験結果を整理した。しかし、回転全面横圧縮では材せい方向の歪度分 布が一定であるとは考え難いため、ここで得られる応力度一歪度関係が等変 位全面横圧縮で得られる応力度一歪度関係と性質が異なることが予想される。

そこでまずは、等変位全面横圧縮と回転全面横圧縮の降伏応力度を比較す ることにした。ここで、降伏応力度とは応力度一歪度関係を文献 9）に示し た手法でバイリニアに近似したときに得られる折れ点の応力度である。表 A1 がその結果であり、明らかに回転全面横圧縮の方が高いことが分かる。そし て、それらの比は、様々な材幅・材せいの結果において 1.5 程度で安定して いることから、本論の解析では等変位全面横圧縮実験より得た降伏応力度を 1.5 倍して用いた。なお、応力度一歪度関係の第一勾配と第二勾配は、等変位 全面横圧縮と回転全面横圧縮で等しいとした。

表 $A 1$ 等変位全面横圧縮と回転全面横圧縮の降伏応力度 ${ }^{8)}$

\begin{tabular}{c|c|c|c|c}
\hline \hline \multirow{2}{*}{$\begin{array}{c}\text { 材幅 } \\
\mathrm{mm}\end{array}$} & 材せい & \multicolumn{2}{|c|}{ 降伏応力度 $\mathrm{N} / \mathrm{mm}^{2}$} & \multirow{2}{*}{ 回転/等変位 } \\
\cline { 3 - 4 } & 等変位 & 回転 & \\
\hline 50 & 50 & 3.81 & 6.52 & 1.71 \\
\hline 200 & 100 & 5.17 & 7.61 & 1.47 \\
\hline 100 & 150 & 3.86 & 6.09 & 1.58 \\
\hline 150 & 200 & 4.12 & 5.93 & 1.44 \\
\hline \hline
\end{tabular}

2) 回転横圧縮における余長の効果

1)で得た回転全面横圧縮の構成則を用いて、回転横圧縮で余長がある場合 の評価を行う。文献 8)で行った実験より、余長の長さとバイリニア近似した ときの第一勾配・降伏応力度の関係を図 A1 のように得た。これより、余長 の存在によって回転めり込みの抵抗力が上昇していることが分かる。

稲山や棚橋は余長部の歪度分布を指数関数と仮定することで、上述の傾向 を再現しているが ${ }^{10,13)}$, 本論ではより簡便な方法として、余長部に三角形状の 歪度が拡がるモデルとした。このとき、図 A 1 において余長 / 加圧長さが 0.5 以上でほぼ一定值となったことを考慮し、歪度の拡がりを加圧面の半分の長 さとして図 16 のような応力状態を考えれば、第一勾配や降伏応力度の上昇が 1.75 倍となり、実験結果を概ね再現できることが分かる。

ただし、この実験は材せいと加圧長さが等しいという条件下で行っている ことを付け加えておく。一般的な仕口で生じる回転横圧縮は、材せいと加圧 長さが概ね等しい場合が多いと考えられ、本論にもこの結果を適用すること としたが、既往文献 ${ }^{10,13)}$ には余長効果が材せいの影響を受けることを示した ものがある。したがって、図 11 に示す $F_{c y}$ と呼ぶめり込夕抵抗力に関しては、 厳密には本評価法の適用外となるが、このモデルを用いた本論の解析で得た
$M-\theta$ 関係はもちろん、中立軸位置 $x_{n}$ の推移 (図 A2) も実験結果と良く対応 していたため、この部分の多少の誤差は、全体挙動や局所挙動にそれほど大 きな影響を与えないと判断した。これについては今後の研究課題としたい。
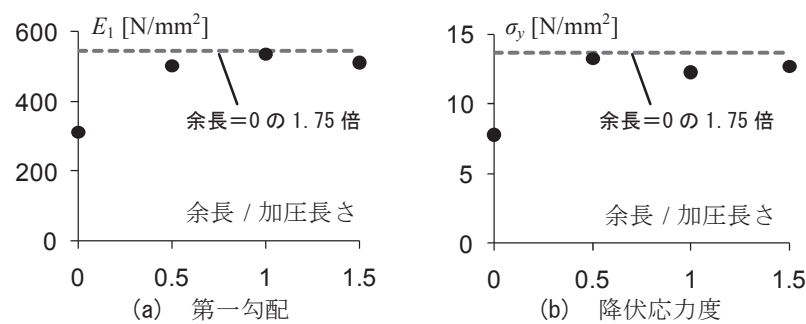

図 A1 余長が及ぼす影響

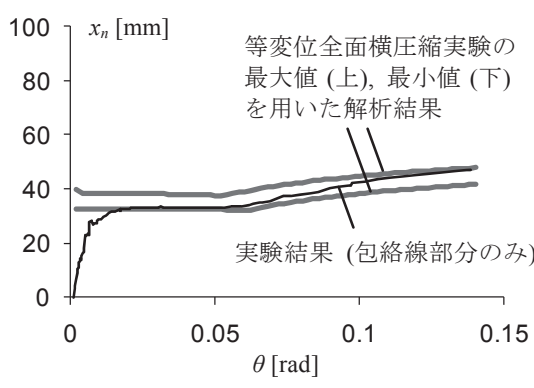

図 A2 中立軸位置 $x_{n}$ の推移 (No.5-CC)

\section{付録 B 込栓のせん断による抵抗力の算定}

込夕栓のせん断による抵抗力の算定あたって必要な、弾性剛性と降伏応力 の評価式を以下に示す。文献 12）における木ダボ接合（せん断抵抗型）の 2 面せん断として扱うことで、 $K_{d x}, K_{d y}$ を以下のように得る。

$$
\begin{aligned}
& K_{d x}=K_{x p} K_{x b} /\left(K_{x p}+K_{x b}\right), \quad K_{d y}=K_{y p} K_{y b} /\left(K_{y p}+K_{y b}\right) \\
& K_{x p}=\min \left[d k_{c p x, p} b, \frac{1}{3}\left(E_{d} d^{7} k_{c p x, p}^{3}\right)^{1 / 4}\left(1+0.188 \eta \sqrt{k_{c p x, p} d / E_{d}}\right)^{-1 / 2}\right] \\
& K_{x b}=\min \left[d k_{c p x, b}(B-b) / 2, \frac{1}{3}\left(E_{d} d^{7} k_{c p x, b}^{3}\right)^{1 / 4}\left(1+0.188 \eta \sqrt{k_{c p x, b} d / E_{d}}\right)^{-1 / 2}\right] \\
& K_{y p}=\min \left[d k_{c p y, p} b, \frac{1}{3}\left(E_{d} d^{7} k_{c p y, p}^{3}\right)^{1 / 4}\left(1+0.188 \eta \sqrt{k_{c p y, p} d / E_{d}}\right)^{-1 / 2}\right] \\
& K_{y b}=\min \left[d k_{c p y, b}(B-b) / 2, \frac{1}{3}\left(E_{d} d^{7} k_{c p y, b}^{3}\right)^{1 / 4}\left(1+0.188 \eta \sqrt{k_{c p y, b} d / E_{d}}\right)^{-1 / 2}\right]
\end{aligned}
$$

ここに、 $E_{d}=$ 込栓のヤング係数、 $\eta=$ ヤング係数とせん断弾性係数の比 ( = $15)$ である。 $k_{c p x, p}, k_{c p y, p}=x$ 方向 $\cdot y$ 方向の柱と込栓の複合面圧定数、 $k_{c p x, b}, k_{c p y, b}$ $=x$ 方向 $\cdot y$ 方向の横架材と込栓の複合面圧定数であり、次式より得る。

$$
\begin{array}{ll}
k_{c p x, p}=k_{E p(0)} \alpha_{k} k_{c v f} /\left(k_{E p(0)}+\alpha_{k} k_{c v f}\right) & k_{c p x, b}=k_{E b(0)} \alpha_{k} k_{c v f} /\left(k_{E b(0)}+\alpha_{k} k_{c v f}\right) \\
k_{c p y, p}=k_{E p(90)} \alpha_{k} k_{c v f} /\left(k_{E p(90)}+\alpha_{k} k_{c v f}\right) & k_{c p y, b}=k_{E b(90)} \alpha_{k} k_{c v f} /\left(k_{E b(90)}+\alpha_{k} k_{c v f}\right) \\
k_{E p(0)}=E_{p} /(31.6+10.9 d) & k_{E p(90)}=k_{E p(0)} / 3.4 \\
k_{E b(0)}=E_{b} /(31.6+10.9 d) & k_{E b(90)}=k_{E b(0)} / 3.4
\end{array}
$$

ここに、 $k_{E p(0)}$ と $k_{E p(90)}$ は、それぞれ柱の繊維方向・繊維直交方向への面圧定数 であり、同様に $k_{E b(0)}$ と $k_{E b(90)}$ は、横架材の繊維方向・繊維直交方向への面圧定 数である。また、 $k_{c v f}$ は込み栓のめり込み剛性、 $\alpha_{f}$ はめり込み降伏増大係数で あり、1.5 を用いる。

また、降伏耐力は以下のように求める。

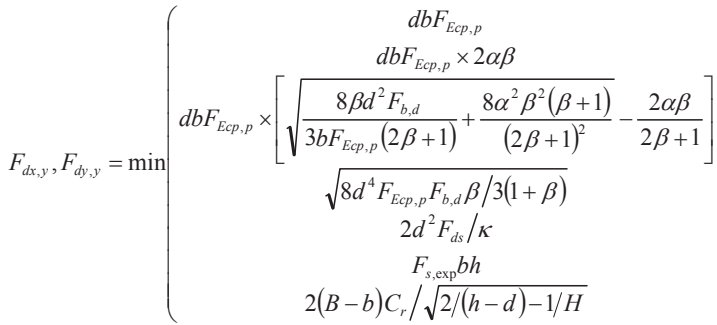

(A4a-g) 
ここに、 $\alpha=(B-b) / 2 b, \beta=F_{E c p, b} / F_{E c p, p}, F_{b, d}=$ 込栓の曲げ強度、 $\kappa=$ せん断補 正係数 (=1.5) である。 $F_{E c p, b}$ と $F_{E c p, p}$ は、それぞれ柱と横架材の複合面圧降 伏応力であり、

$$
F_{E c p, p}=\min \left(F_{E, p}, \alpha_{k} F_{c v f}\right) \quad, \quad F_{E c p, b}=\min \left(F_{E, b}, \alpha_{k} F_{c r f}\right)
$$

のように求める。 $F_{E, p}$ と $F_{E, b}$ は、それぞれ柱と横架材の面圧降伏応力、 $F_{c v f}$ は 込栓のめり込み降伏応力である。式(A1),(A4)の算定に必要な $E_{d}, k_{c v y}, F_{b, d}, F_{E, p}$, $F_{E, b}$ は密度による回帰式を用い、 $E_{p}, E_{b}, F_{s, e x p}$ は材料実験より得た值を用いた。

\section{付録 C 摩擦係数の影響}

木材同士の摩擦係数は、摩擦面の表面状態や木材の纎維方向に影響を受け るとされており、本論のような曲げ解析にあたっては、別途実験を行って摩 擦係数を計測する例もある ${ }^{13)}$ 。そこで、本論の曲げ解析で得た結果に対し、 摩擦係数の変化がどの程度影響を与えるのかを示しておく。

図 A3 は試験体 No1-HH で、全面横圧縮実験で得られる各特性值の平均值 を用いた解析結果であり、摩擦係数として $0.2,0.4,0.6$ の 3 種を用いた場合の 比較である。摩擦係数が 0.2 の場合を基準として初期剛性やほぞのせん断破
壊が生じるときのモーメントを比べると、摩擦係数 0.4 では $17 \%$ 程度、0.6で は35\%程度上昇した。このように、摩擦係数は解析結果に対して無視できな いほどの影響を与え、摩擦係数を詳細な実験により求める必要性も示唆され る。しかし、曲げ実験から得た $M-\theta$ 関係が大きくばらついていたように、 摩擦係数自体にも大きなばらつきがあることも知られているため ${ }^{13)}$, 本論で は文献 11）の值を転用し、結果の上限と下限を抑えることを主目的とした。

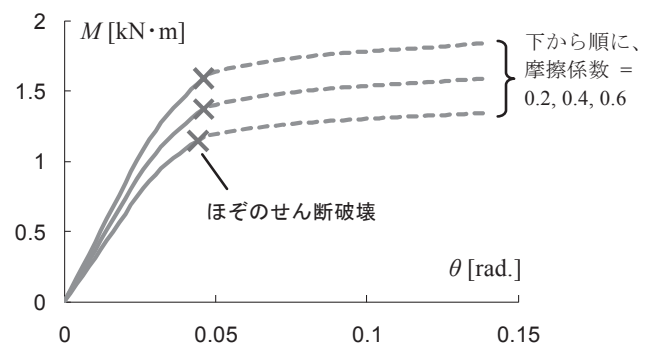

図 A3 摩擦係数が $M-\theta$ 関係に及ぼす影響 (No.1-HH)

（2011年 7 月 8 日原稿受理，2011年10月12日採用決定） 